\title{
Lifetime and optical analyses of LED lamps
}

\section{Análises ópticas e tempo de vida de lâmpadas LED}

\author{
Emerson Roberto Santos ${ }^{1,2, *}\left(\mathbb{D}\right.$, Helio Akira Furuya ${ }^{3}$, Elvo Calixto Burini Junior ${ }^{4}$ (D) \\ 1. Escola Politécnica da Universidade de São Paulo - Engenharia Metalúrgica e de Materiais - São Paulo (SP), Brazil. \\ 2. Laboratório SuperCriativo - São Paulo (SP), Brazil.
}

3. Faculdade de Tecnologia de São Paulo - Microeletrônica - São Paulo (SP), Brazil.

4. Universidade de São Paulo - Instituto de Energia e Ambiente - São Paulo (SP), Brazil.

Correspondence author: cientistaemersonsantos@gmail.com

Section Editor: Maria Lúcia Pereira da Silva

Received: 10 Jun 2021 Approved: 20 Jul 2021

\begin{abstract}
In this study, optical and lifetime analyses of commercial light-emitting diode (LED) lamps were carried out with the objective to better understand these characteristics. Lamps of different manufacturers and powers were used: Ourolux of 9 watts, Kian of 9 watts, Black+Decker of 9 watts, FLC of 8 watts, Galaxy of 7 watts and Brilia of 7 watts. These LED lamps remained on by 24 hours/day for 4,291.16 hours. Illuminance measurements were analyzed once a week by each lamp inside the integrating sphere with a sensor of lux meter coupled. Results showed decrease of illuminance by elapsed time, due to the degradation. Results of the illuminance obtained between the initial moment of the experiment and the final one were calculated, revealing degradation of $19 \%$ to Ourolux, 20\% to FLC, 26\% to Black+Decker, 28\% to Kian, 29\% to Galaxy and $33 \%$ to Brilia. This study suggests that the diffusers can have different transmittance values interfering on the illuminance, since the FLC LED lamp presented illuminance with highest values than the other LED lamps tested with similar electrical and optical characteristics. This experiment showed that the nominal power of the LED lamp has no direct relation to the illuminance and, comparing the lifetime, the LED lamp manufactured by Black+Decker was the only one to reach 5,521 hours, that is a lifetime much shorter than the one described at the packages (25,000 hours) for all LED lamps tested.
\end{abstract}

KEYWORDS: LED lamp, Illuminance, Lifetime, Efficiency.

\section{RESUMO}

Neste estudo, analises ópticas e de tempo de vida de lâmpadas LED comerciais foram realizadas com o objetivo de melhor entender essas características. Lâmpadas de diferentes fabricantes e potências foram usadas: Ourolux de 9 watts, Kian de 9 watts, Black+Decker de 9 watts, FLC de 8 watts, Galaxy de 7 watts e Brilia de 7 watts. Essas lâmpadas permaneceram ligadas por 24 horas/dia ao longo de 4.291,16 horas. Medidas de iluminância foram analisadas uma vez por semana para cada lâmpada no interior de uma esfera integradora com um sensor de luxímetro acoplado. Resultados mostraram a diminuição da iluminância pelo tempo decorrido, por causa da degradação. A iluminância obtida entre o início do experimento e o momento final foi calculada, revelando degradação de: 19\% para a Ourolux, 20\% para a FLC, 26\% para a Black+Decker, 28\% para a Kian, 29\% para a Galaxy e 33\% para a Brilia. Este estudo sugestiona que os difusores podem ter diferentes valores de transmitâncias interferindo na iluminância, uma vez que a lâmpada LED da FLC apresentou iluminância com mais altos valores do que as outras lâmpadas LEDs testadas com similares características elétricas e ópticas. Este experimento mostrou que a potência nominal da lâmpada LED não tem relação direta com a iluminância, e, em comparação com o tempo de vida, a lâmpada LED fabricada pela Black+Decker foi somente a única a alcançar 5,521 horas, que é um tempo muito mais curto do que o descrito nas embalagens de todas as lâmpadas LEDs testadas, de 25 mil horas.

PALAVRAS-CHAVE: lâmpadas de LED, Iluminância, Vida útil, Eficiência. 


\section{INTRODUCTION}

Light-emitting diode (LED) lamp is known as a solid-state lighting, because of the LED, that is a semiconductor device invented by Nick Holonyak, Jr. in 19601. This semiconductor electronic component transforms electrical current in visible light with high luminosity. For this reason, it has been very used in low power lamps ${ }^{2}$. Differently of incandescent and fluorescent lamps, LED ones do not operate at high temperatures, neither use confined gas inside the discharge glass tubes or filament heated to transform electrical energy in light3,4.

Before years, LEDs were used only to signalization (very common in some electronic equipment), due to the limited emission and restrict range of light color emission, but at the middle of the 1990s the engineer and PhD Shuji Nakamura, from Nichia Corporation, discovered the LED with blue emission ${ }^{5}$. Then, on surface of this device, a phosphor layer was applied to generate white light emission ${ }^{6}$. After this, the use of LED to illuminate rooms or displays with vast gamut of colors started ${ }^{7-9}$. Some LED lamp formats were used from the initial commercialization, but the most frequent format nowadays has been supplied as pear shape (as also presented by incandescent lamps) ${ }^{10}$. Figure 1 presents the complete composition of a LED lamp (manufactured by Black+Decker company) available in the Brazilian market ${ }^{11}$.

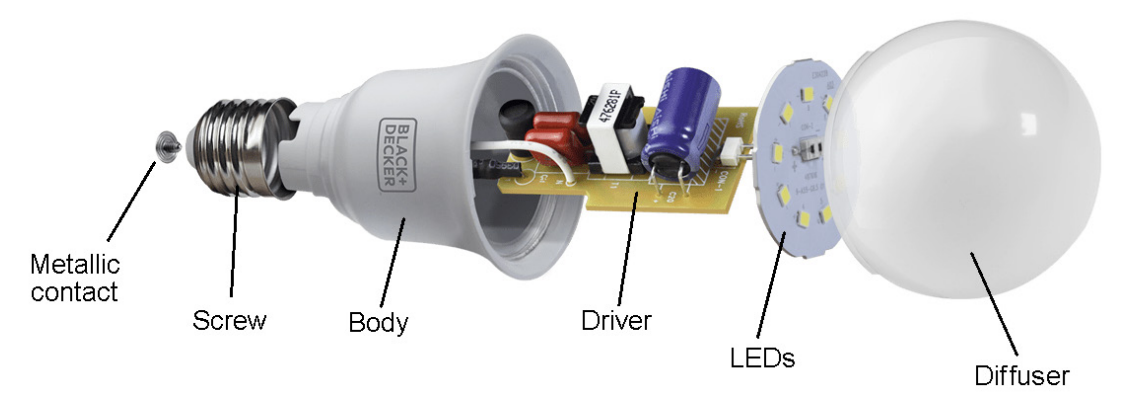

Figure 1: Complete composition of light-emitting diode (LED) lamp available in the Brazilian market.

The diffuser used in lamp protects the LEDs and promotes the dispersion of the light flux. LEDs used in lamps are mounted on the metallic board to dissipate the heat generated ${ }^{12}$. Driver (electronic circuit) with some semiconductor electronic components is used in the conversion of line energy ${ }^{13}$. Generally, all LEDs are electrically connected in serial (maintaining the same level current for all devices and the total voltage supplied by driver, which is divided for each LED). Comparing all source lights developed by humans, the LED lamps are the most important, due to the benefits promoted by LEDs, such as ${ }^{14,15}$ : low power consumption, high efficiency, environmentally friendly (LED lamps contain no toxic chemical elements), large range of visible light wavelengths, no ultraviolet and infrared emission and positional light beam.

This study is based on consumer's reports, since LED lamps present low performance - much less than the 25,000 hours described at the packages by some manufacturers. Lifetime found for LED lamps has been very different than the announced by companies. Moreover, new companies without tradition on the business lighting have been distributing LED lamps in Brazilian market using semiconductor electronic components (as examples: resistors, electrolytic capacitors, diodes, integrated circuits, and LEDS) from unknown suppliers with traditional microelectronic industry to assemble the drivers. Drivers are responsible by converting alternating current (AC) of line energy in direct current (DC) to operate the LEDs. The driver used to operate the LEDs needs to provide precise power avoiding peaks of energy that jeopardize the performance of LEDs.

Another critical control is related to the operating temperature of the semiconductor electronic components that must be below the maximum limit supported to avoid premature failure for LED lamps. In this case, the most common problem that occurs in drivers and has contributed by increase of temperature inside the lamp is the drying of electrolytic capacitors or the leakage of its intern dielectric (material capable of storing energy $)^{16}$.

Drivers are basically composed by three steps, such as 17,18: input electrical circuit from energy line, electrical control of energy, and electrical connection of LEDs. Figure 2 shows as example a driver with front and verse sides that was extracted from a LED lamp of 7 watts manufactured by Galaxy company. It is possible to see the use of electrolytic capacitors and some surface mounted devices (SMDs). 

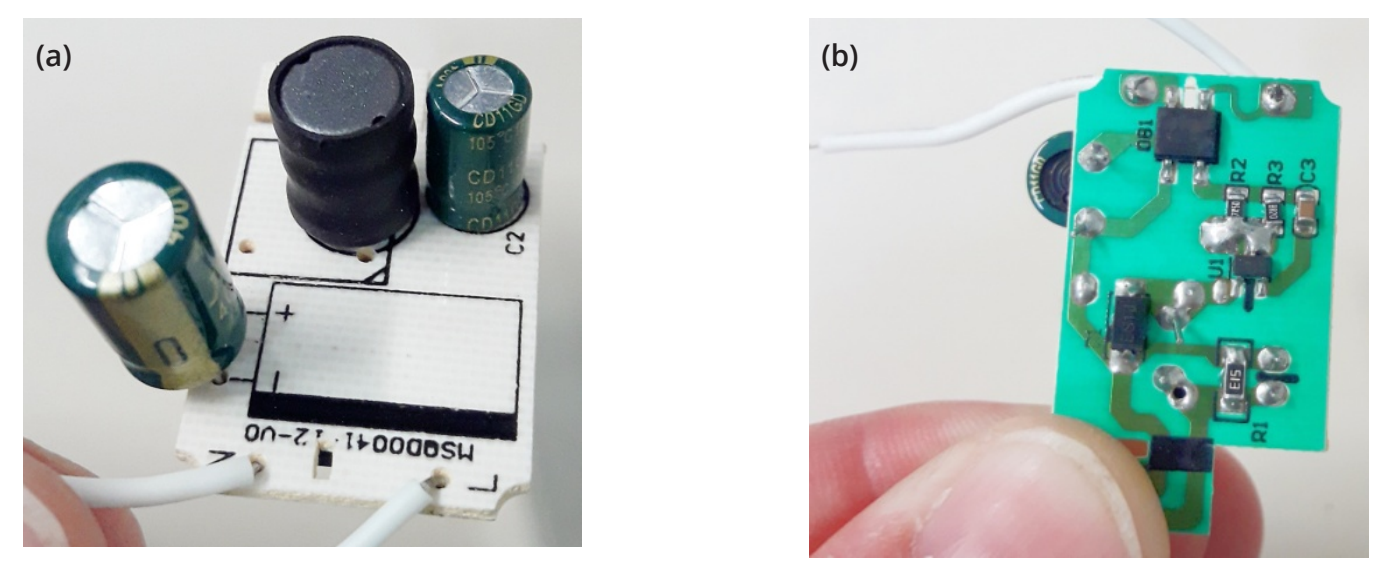

Figure 2: Driver extracted from light-emitting diode (LED) lamp of 7 watts: (a) front side; (b) verse side.

This study is related to the lifetime and, consequently, decrease of illuminance for some LED lamps available in Brazilian market.

\section{MATERIALS AND METHODS}

The objective of this work was to study the illuminance behavior for LED lamps mounted in rack and polarized by 24 hours/day for 178 days, totalizing the period of 4,291.16 hours. This investigation used six LED lamps with E-27 screw, 6,500 Kelvin and different nominal power of some companies available in Brazilian market:

- Ourolux of 9 watts (806 lumens);

- Kian of 9 watts (810 lumens);

- Black+Decker of 9 watts (803 lumens);

- FLC of 8 watts (806 lumens);

- Galaxy of 7 watts (600 lumens);

- Brilia of 7 watts (600 lumens).

Figure 3 shows the rack containing the six LED lamps tested.

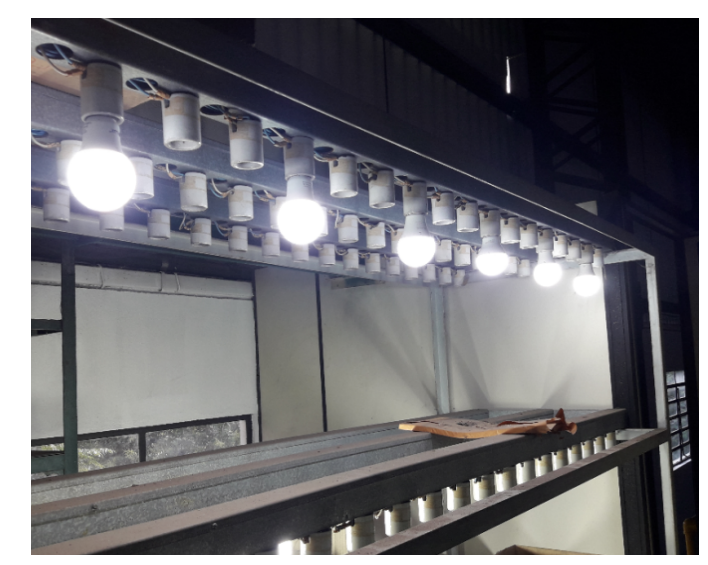

Figure 3: Rack with six light-emitting diode (LED) lamps left on for 24 hours/day.

In the illuminance measurements, a luxmeter manufactured by Minipa, model MLM-1332, coupled with an integrating sphere was used. Each LED lamp was removed of the rack and polarized inside the integrating sphere after 10 minutes to complete stabilization. The optical analyses were obtained once a week.

Figure 4 shows the integrating sphere with the sensor of luxmeter coupled. 


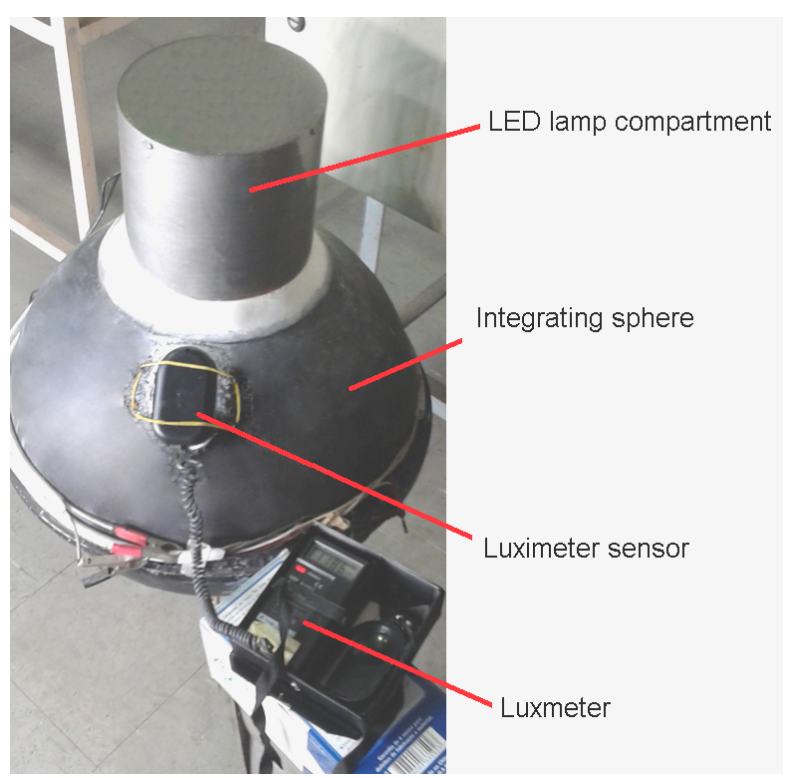

Figure 4: Integrating sphere with light-emitting diode (LED) lamp compartment and sensor of luxmeter coupled.

\section{RESULTS}

Results for LED lamps measured until 4,291.16 hours showed decays of illuminance by elapsed time, presenting low variations for all LED lamps tested. The hypothesis for this behavior can be related to the temperature operation of LEDs and the temperature reached by electronic devices that compose the drivers. The illuminance analyses were carried out at room temperature. Therefore, this parameter was not controlled during the tests. In the total period of analyses (4,291.16 hours), only the LED lamp manufactured by Kian presented failure (it stopped completely). Figures 5 to 10 show the illuminance vs. elapsed time analyses for all LED lamps tested.

Results presented by Figs. 5 to 10 show different values of illuminance for all LED lamps analyzed, with accentuated decline between 500 and 1,000 hours caused by unknown reasons. The attenuation of light can be attributed to the plastic material of the diffuser, but, comparing the LED lamps with the same power, it was possible to verify that Black+Decker presented superior performance than Kian and Ourolux (all of 9 watts). Brilia LED lamp presented better results compared to Galaxy (both of 7 watts). FLC LED lamp revealed the highest illuminance compared with all LED lamps tested, showing that the consumed power has no direct relation to the amount of light produced. It was also observed that this lamp presented low variations after 1,000 hours.

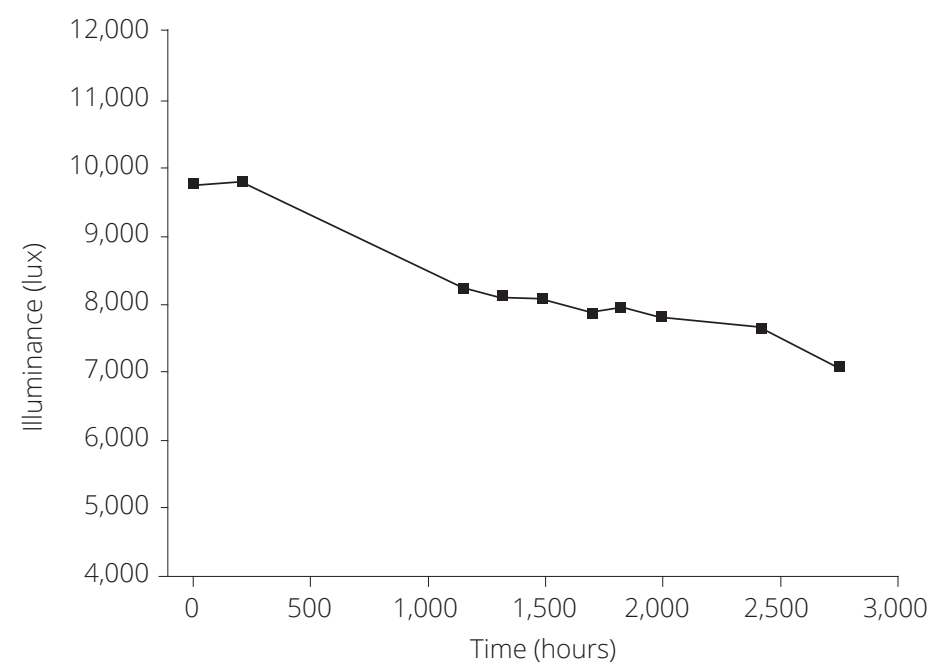

Figure 5: Illuminance vs. time for light-emitting diode (LED) lamp of Kian with 9 watts. 


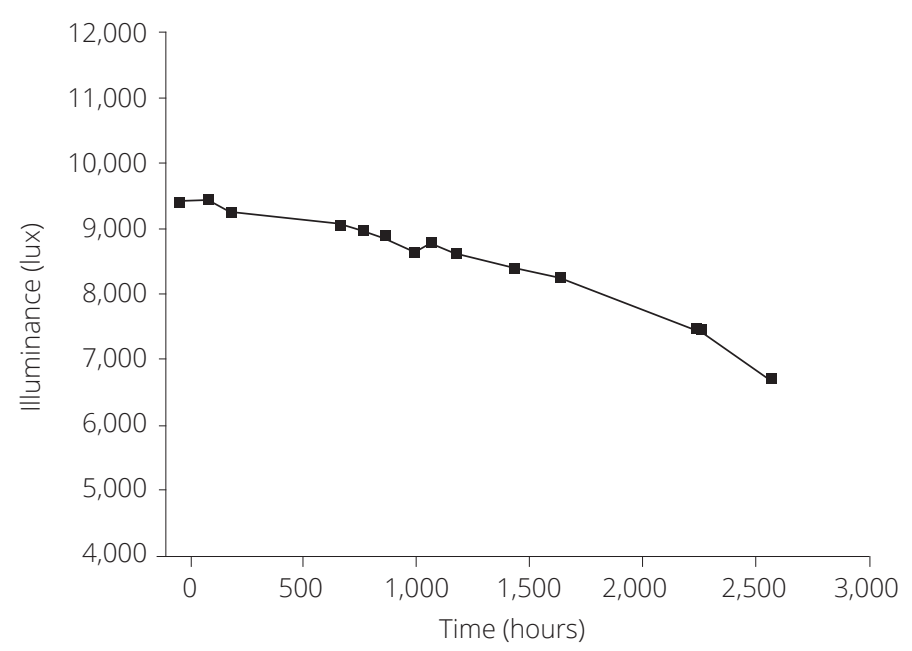

Figure 6: Illuminance vs. time for light-emitting diode (LED) lamp of Ourolux with 9 watts.

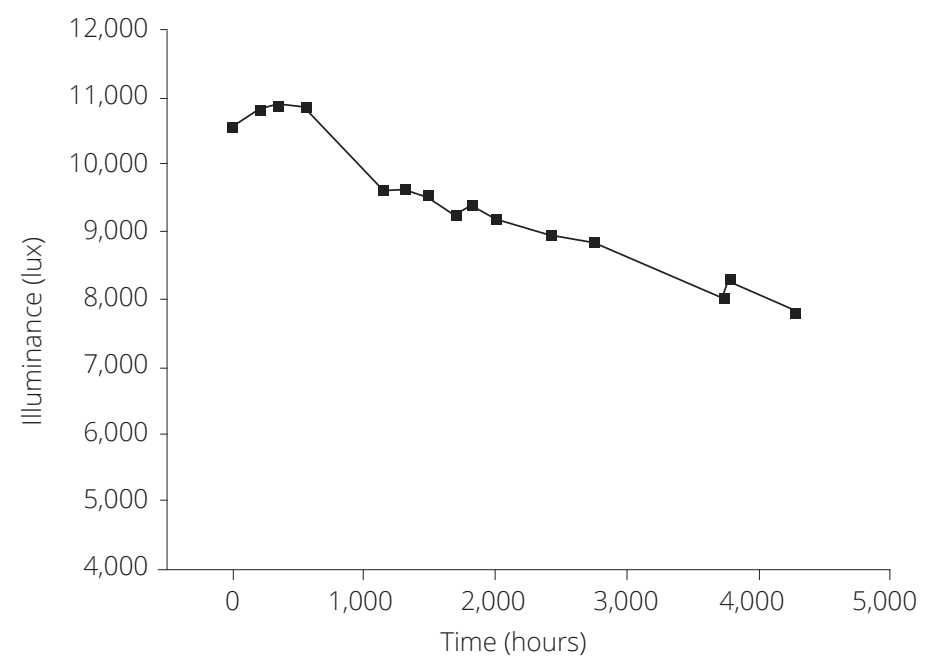

Figure 7: Illuminance vs. time for light-emitting diode (LED) lamp of Black+Decker with 9 watts.

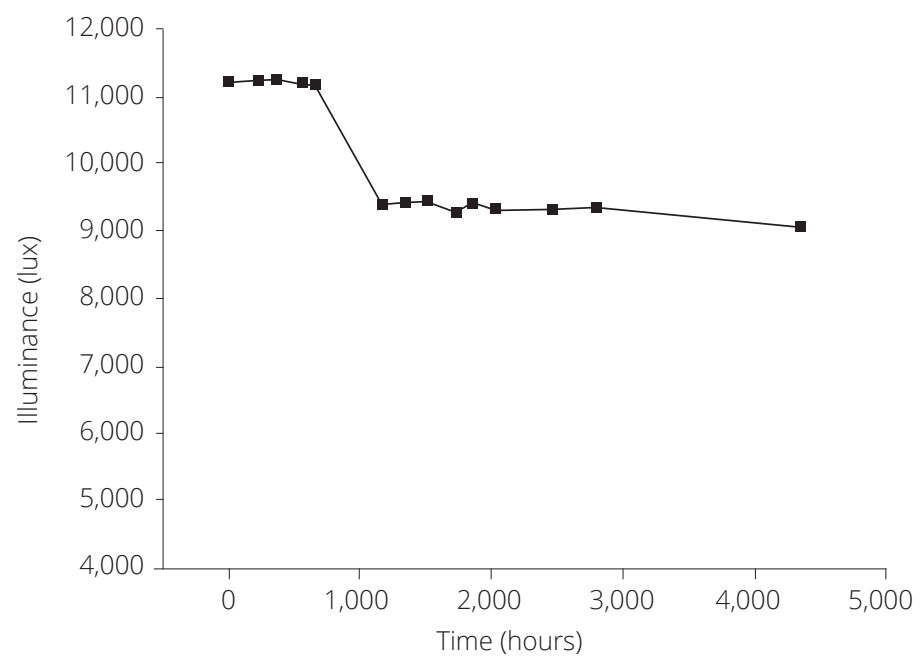

Figure 8: Illuminance vs. time for light-emitting diode (LED) lamp of FLC with 8 watts. 


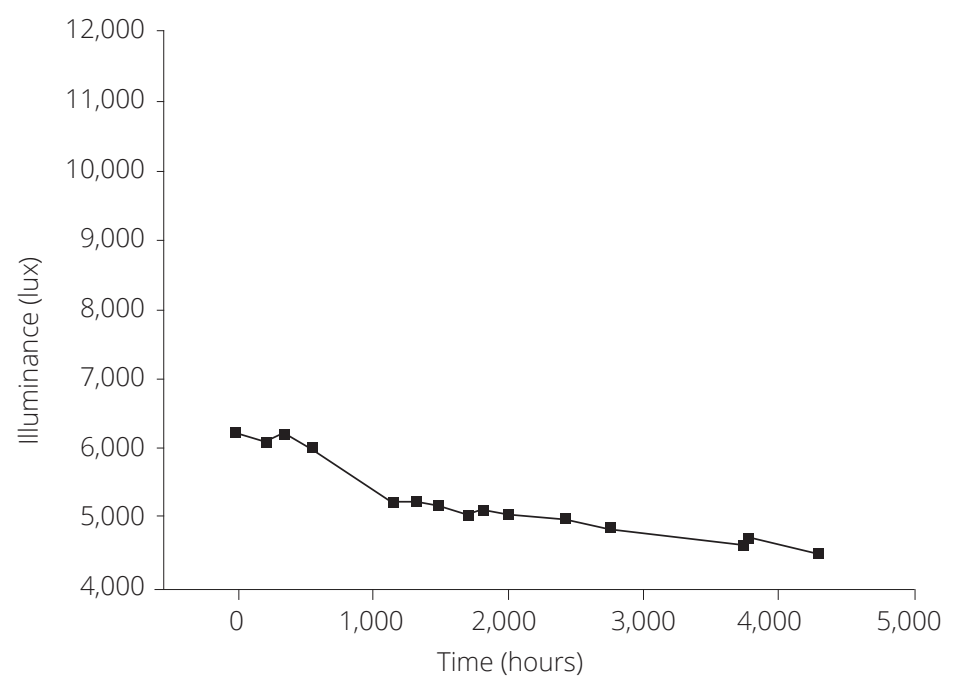

Figure 9: Illuminance vs. time for light-emitting diode (LED) lamp of Galaxy with 7 watts.

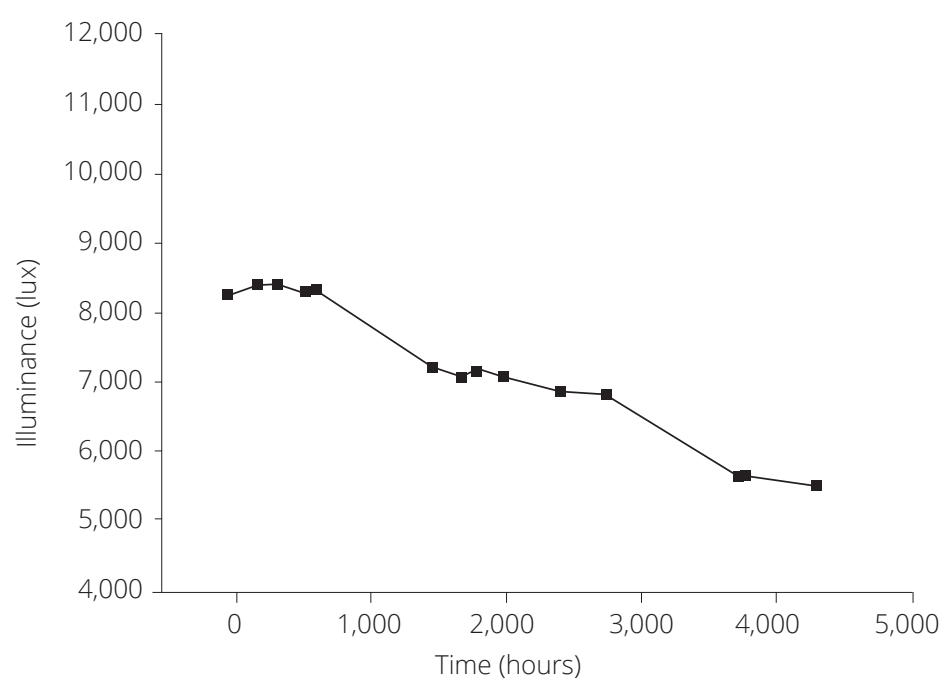

Figure 10: Illuminance vs. time for light-emitting diode (LED) lamp of Brilia with 7 watts.

The degradation of illuminance for each LED lamp could be analyzed by the variation of percentage obtained from the initial moment of the measurements (highest value) and the final one (lowest values): 19\% for Ourolux, 20\% for FLC, 26\% for Black+Decker, 28\% for Kian, 29\% for Galaxy and 33\% for Brilia. As this experiment used only one LED lamp from each company, the results obtained represent low precision, but, in general terms, it was possible to verify the degradation of illuminance by elapsed time for all LED lamps tested. The hypothesis to decrease the performance can be attributed to the intern high temperature reached by the semiconductor electronic components inside the body of the lamp and high temperature of LEDs operation inside the diffuser ${ }^{19}$. Then, it is suggested to maintain the temperature stable and below of maximum operation temperature pre-established to the semiconductor electronic components (LEDs, diodes, resistors, integrated circuits, and electrolytic capacitors, mainly) used to the composition of the LED lamp. The heat is excessive especially on summer days, further contributing to the low performance.

\section{CONCLUSION}

In this study, commercial LED lamps with different powers obtained from some companies were on 24 hours/ day for 4,291.16 hours, totalizing 178 days, mounted in a rack. The analyses of illuminance by elapsed time 
revealed different behaviors for all LED lamps at same power consumption. This characteristic can be attributed by transmittance of plastic diffuser, that can be constituted of different materials.

The results of illuminance by elapsed time showed decreases of values that can be related to the degradation due to the internal heat, decreasing the performance of LEDS and semiconductor electronic components used for the driver. The performance for each LED lamp can be analyzed by the variation of percentage obtained from the highest (initial measurements) and the lowest (final measurements) values of illuminance: 19\% for Ourolux, 20\% for FLC, 26\% for Black+Decker, 28\% for Kian, 29\% for Galaxy and 33\% for Brilia.

After analyses of these LED lamps by 4,291.16 hours, they remained on, and it was observed that the Black+Decker lamp was the only one to reach 5,521 hours. For the next experiment using the same method, it is suggested the use of some lamps manufactured by Black+Decker with same optical characteristics to confirm this result. This maximum lifetime is still very low, if compared with the information described at the packages, of 25,000 hours.

\section{ACKNOWLEDGMENTS}

The authors thank the Escola Politécnica of Universidade de São Paulo, Engenharia Metalúrgica e de Materiais and Instituto de Energia e Ambiente of Universidade de São Paulo, for providing facilities and equipments.

\section{AUTHOR'S CONTRIBUTION}

Conceptualization, Data curation, Formal analysis, Funding acquisition, Methodology, Resources, Software, Supervision, Visualization, Writing - Original Draft, Writing - Review \& Editing: Santos ER; Data curation, Formal analysis, Software, Supervision, Visualization, Writing - Original Draft, Writing - Review \& Editing: Furuya HA; Data curation, Formal analysis, Software, Supervision, Visualization, Writing - Original Draft, Writing - Review \& Editing: Burini Junior EC.

\section{FUNDING}

This study was funded by Coordenação de Aperfeiçoamento de Pessoal de Nível Superior (Capes)

[http://doi.org/10.13039/501100002322]

PNPD Project No 02998/09-2.

\section{DATA AVAILABILITY STATEMENT}

Data are available in a data repository.

Furuya H A. Estudo De Desempenho de Lâmpadas LEDs

[undergraduate thesis]. São Paulo: Faculdade de Tecnologia de São Paulo; 2020.

\section{REFERENCES}

1. Slocum A. A technology assessment of light emitting diode (LED) [Internet]. Washington, D.C.: National Center for Environmental Economics; 2005 [cited on Aug 16, 2021]. 91 p. Available from: https://www.epa.gov/sites/ production/files/2014-12/documents/technology_assessment_of_light_emitting_diode.pdf

2. Batra S, Pandav CS, Ahuja S. Light emitting diode lighting flicker, its impact on health and the need to minimise it. J Clin Diagn Res. 2019;13(5):1-5. https://doi.org/10.7860/JCDR/2019/41491.12880

3. Hazrati MI. Comparison of light efficiencies between high intensity discharge (HID) and light emitting diodes (LED) lights. J Phys Astron Res. 2019;5(2):94-96. 
4. Rovnag R. Effect on the environmental and energy-saving of white LEDs applied in the lighting and future benefits in term of economics. In: 55th International Scientific Conference on Economic and Social Development, Baku; 2020. Proceedings [Internet]. 2020 [cited on Aug 16, 2021];40-6. Available from: https://www.researchgate.net/profile/ Avaz_Alakbarov/publication/347524814_INTERNATIONAL_EXPERIENCE_ON_INSURANCE_OF_FARMS_FROM_ EXPORT_RISKS_EXISTING_PROBLEMS_AND_PERSPECTIVES_IN_AZERBAIJAN/links/5feof8dc45851553a0df10be/ INTERNATIONAL-EXPERIENCE-ON-INSURANCE-OF-FARMS-FROM-EXPORT-RISKS-EXISTING-PROBLEMS-ANDPERSPECTIVES-IN-AZERBAIJAN. pdf\#page=51

5. Celen IH. Lighting on agriculture and using light emitting diodes. Int J Innov Eng Sci Res [Internet]. 2019 [cited on Aug 16, 2021];3(5):81-93. Available from: http://www.jijesr.com/liebrary/e22/922426952.pdf

6. Won Y-H, Jang HS, Cho KW, Song YS, Jeon DY, Kwon HK. Effect of phosphor geometry on the luminous efficiency of high-power white light-emitting diodes with excellent color rendering property. Opt Lett. 2009;34(1):1-3. https://doi.org/10.1364/OL.34.000001

7. Philips. Unleash your imagination even more. LED Display for every form and shape. Philips Catalogue [Internet]. Philips; 2020 [cited on Aug 16, 2021]. 3 p. Available from: https://www.philips.com/c-dam/b2c/professionalcatalog/professionaldisplays/homepage/featured-products/led-7000-series/22BDL7324L_00.pdf

8. Sony. Value Electronics. Don't just display: crystal LED display system [Internet]. Sony; 2019 [cited on Aug 16, 2021]. 6 p. Available from: https://www.valueelectronics.com/uploads/Sony_Crystal-LED_Brochure.pdf

9. Philips. Philips LED Lighting. Professional LED lighting catalog [Internet]. Philips; 2020 [cited on Aug 16, 2021]. 98 p. Available from: https://www.assets.signify.com/is/content/PhilipsLighting/Assets/philips-lighting/ global/20200212-led-lighting-catalog-q1-2020.pdf

10. Philips. Philips Lighting. Standard A-shape clear. Catalogue [Internet]. Philips; 2021 [cited on Aug 16, 2021 ]. 2 p. Available from: https://www.assets.lighting.philips.com/is/content/PhilipsLighting/fp920056542905-pss-global

11. Black+Decker. Iluminação. Vantagens LED [Internet]. Black+Decker; 2020 [cited on Aug 16, 2021]. Available from: http://bdiluminacao.com.br/led/

12. Bergquist. Thermal management for LED [Internet]. Bergquist; 2017 [cited on Aug 16, 2021]. 6 p. Available from: https://dm.henkel-dam.com/is/content/henkel/tt-8151-brochure-thermal-management-solutions-for-led

13. Oshino. LEDs for signs. Your guide to LED drivers [Internet]. Oshino; 2020 [cited on Aug 16, 2021]. 9 p. Available from: http://www.oshino-lamps.co.uk/pdfs/DRIVERS.pdf

14. Arquitetizze. Vantagens de utilizar lâmpadas LED. Arquitetizze [cited on June 20, 2020]. Available from: http:// arquitetizze.com.br/saiba-quais-sao-as-vantagens-de-utilizar-lampadas-led/

15. Any-Lamp.com. Professional LED \& Light. LED lamp vs incandescent light bulb [Internet]. Any-Lamp.com [cited on Aug 16, 2021]. Available from: https://www.any-lamp.com/blog/led-vs-incandescent

16. Oliveira FC. Previsibilidade de falhas em capacitores do barramento c.c de inversores de frequência [dissertation online]. Minas Gerais: Universidade Federal de Minas Gerais; 2012 [cited on Aug 16, 2021]. Available from: https://repositorio.ufmg.br/handle/1843/30384

17. Renato GL. Os LEDs na iluminação e a suas vulnerabilidades [Internet]. MTec Energia [cited on Aug 16, 2021]. 9 p. Available from: https://s1p.studylibpt.com/store/data/001583294.pdf?k=AwAAAXdPpQ1WAAACWLOI3ly2enO85BONqNLzsX6bc7c

18. Friwo. Basics of LED drivers - functions - requirements - selection. Friwo energy for life your solution our innovation [Internet]. Friwo; 2015 [cited on Aug 16, 2021]. 7 p. Available from: https://www.melconindia.com/ img/product/5/T3D_design_LED_drivers_basics_E.pdf

19. Santos ER, Burini Junior EC, Hui WSH. Influence of temperature in the performance of the LED lamp. Rev Bras Aplic Vácuo. 2020;39(2):156-67. https://doi.org/10.17563/rbav.v39i2.1171 